\title{
Mengatasi Error Berkorelasi Menggunakan Metode Transformasi Prewhitening pada Regresi Nonparametrik Kernel
}

\author{
Nurasiah Amini ${ }^{a}$, Mustika Hadijati ${ }^{b}$, Qurratul Aini ${ }^{a, b, *}$ \\ ${ }^{a}$ Program Studi Matematika Universitas Mataram, Jl Majapahit No 62, Mataram dan 83125, Indonesia. \\ Email: nurasiahamini6@gmail.com \\ ${ }^{\mathrm{b}}$ Program Studi Matematika Universitas Mataram, J1 Majapahit No 62, Mataram dan 83125, Indonesia. \\ Email: mustika.hadijati@unram.ac.id \\ a,b,* Program Studi Matematika Universitas Mataram, Jl Majapahit No 62, Mataram dan 83125, Indonesia. \\ Email: qurratulaini.aini@unram.ac.id
}

\section{A B S T R A C T}

Suppose that given $n$ data $\left\{\left(X_{1 t}, X_{2 t}, Y_{t}\right)\right\}_{t=1}^{n}$ with nonparametric regression model :

$$
Y_{t}=m\left(X_{t}\right)+\varepsilon_{t} ; t=1,2, \cdots, n
$$

with $m\left(X_{i}\right)$ is a regression function and $\varepsilon_{i}$ is a random errors. In nonparametric regression often found correlated errors, i.e. the error value does not meet the identical and independent assumptions. Correlated errors will adversely affect the estimation model. Correlated errors can be resolved by prewhitening transformation method, a method where the error is assumed to follow the model $\operatorname{ARMA}(p, q)$. Applied on data is shown that regression model was obtained with correlated errors. The error obtained from the conventional Kernel regression model follows the AR (1) model with the value $\emptyset_{1}=0.932$. After the prewhitening transformation, the kernel regression model results from the prewhitening transformation with uncorrelated errors. The MSE value of the conventional Kernel estimation modal is 639203.308 greater than the MSE value of the estimated Kernel prewhitening transformation model that is 290303.832, so the Kernel estimator resulting from prewhitening transformation is more efficient than conventional Kernel estimator.

Keywords: ARMA $(p, q)$, Epanechnikov Kernel Function, Transformasi, Prewhitening.

* Corresponding author.

Alamat e-mail: qurratulaini.aini@unram.ac.id 


\section{A B S T R A K}

Diberikan $\mathrm{n}$ data $\left\{\left(X_{1 t}, X_{2 t}, Y_{t}\right)\right\}_{t=1}^{n}$ mengikuti model regresi nonparametrik

$$
Y_{t}=m\left(X_{t}\right)+\varepsilon_{t} ; t=1,2, \cdots, n
$$

dengan $m\left(X_{i}\right)$ merupakan fungsi regresi dan $\varepsilon_{i}$ adalah error. Dalam regresi nonparametrik seringkali ditemukan error berkorelasi, yaitu nilai error tidak memenuhi asumsi identik dan independen. Error yang berkorelasi akan berakibat buruk pada model estimasi. Error berkorelasi dapat diatasi dengan metode transformasi prewhitening yaitu suatu metode dimana error diasumsikan mengikuti model $\operatorname{ARMA}(p, q)$. Penerapan pada data menunjukkan bahwa estimasi Kernel konvensional memiliki error berkorelasi. Error yang diperoleh dari model regresi Kernel konvensional mengikuti model AR (1) dengan nilai $\emptyset_{1}=0.932$. Setelah dilakukan transformasi prewhitening diperoleh model regresi Kernel hasil transformasi prewhitening dengan error tidak berkorelasi. Nilai MSE dari model estimasi Kernel konvensional adalah 639203.308 lebih besar dari nilai MSE model estimasi Kernel hasil transformasi prewhitening yaitu 290303.832, sehingga estimator Kernel hasil prewhitening lebih efisien dari estimator Kernel konvensional.

Keywords: ARMA $(p, q)$, Fungsi Kernel Epanechnikov, Transformasi, Prewhitening.

Diserahkan: 17-12-2019; Diterima: 31-12-2019;

Doi: https://doi.org/10.29303/emj.v1i2.42

\section{Pendahuluan}

Pendekatan regresi dibedakan menjadi dua yaitu pedekatan parametrik dan pendekatan nonparametrik. Pendekatan parametrik merupakan pemodelan regresi yang terikat dengan asumsi-asumsi dalam regresi seperti multikolinearitas, residual normalitas, homoskedastisitas residual, dan nonautokorelasi. Sedangkan regresi nonparametrik dilakukan jika bentuk kurva regresinya tidak diketahui dan diasumsikan smooth yang termuat dalam suatu ruang fungsi tertentu (Eubank, 1999). Salah satu metode pendekatan dalam regresi nonparametrik yang digunakan adalah regresi nonparametrik Kernel.

Beberapa teori mengatakan kurva regresi nonparametrik didasarkan pada asumsi bahwa error mengikuti proses white-noise, namun pada penerapannya sering ditemukan error berkorelasi (tidak white-noise). Sebuah proses $\left\{\varepsilon_{t}\right\}$ dikatakan proses white-noise jika tedapat kumpulan variabel random yang tidak berkorelasi dari sebuah distribusi dengan rata-rata $E\left(\varepsilon_{t}\right)=\mu_{\varepsilon}$ biasanya diasumsikan nol, varian $\operatorname{Var}\left(\varepsilon_{t}\right)=\sigma_{\varepsilon}^{2}$ dan $\gamma_{k}=\operatorname{Cor}\left(\varepsilon_{t}, \varepsilon_{t+k}\right)=$ 0 untuk $k \neq 0$ (Wei, 1990). Menurut Opsomer, et al. (2001), error berkorelasi menyebabkan metode seleksi bandwidth menjadi rusak karena dengan peningkatan korelasi, bandwidth yang terpilih akan semakin kecil sehingga estimator makin lama makin kurang smooth. Menurut Xiao, et al. (2002) error yang berkorelasi sebelumnya dapat diasumsikan mengikuti model ARMA $(p, q)$. Untuk mengatasi hal tersebut diperlukan suatu metode transformasi.
Metode yang dapat digunakan untuk mengatasi autokorelasi pada error adalah metode transformasi prewhitening. Transformasi prewhitening adalah suatu metode yang bertujuan untuk mendapatkan error yang white-noise, sehingga diperoleh error yang tidak berkorelasi (Hadijati, 2005). Transformasi prewhitening juga merupakan transformasi dari serangkaian data yang berkorelasi menjadi data yang white noise yang tidak berkorelasi untuk menyederhanakan proses estimasi (Box, Jenkins, Reinsel, 1994).

Hadijati (2005) menggunakan transformasi prewhitening untuk mengatasi error berkorelasi pada regresi nonparametrik Kernel dengan satu variabel prediktor. Namun pada kenyataannya, regresi nonparametrik Kernel bisa lebih dari satu variabel prediktor. Pada penelitian ini dilakukan transformasi prewhitening untuk mengatasi errror berkorelasi pada regresi nonparametrik Kernel dengan dua variabel prediktor serta menerapkannya pada data Indeks Harga Saham Gabungan (IHSG) sebagai variabel respon dengan dua variabel prediktor yaitu Kurs dan Inflasi.

\section{Tinjauan Pustaka}

\subsection{Regresi Nonparametrik}

Analisis regresi merupakan metode statistika yang digunakan untuk mengetahui hubungan antara dua variabel respon $(Y)$ dan variabel prediktor $(X)$. Hubungan variabel $X$ dan $Y$ dapat dituliskan

$Y_{t}=f\left(X_{t}\right)+u_{t} ; t=1,2, \cdots, n$, 
dengan $u_{t}$ adalah galat acak dan $f\left(X_{t}\right)$ merupakan fungsi regresi (Budiantara, 2006).

Fungsi regresi $f\left(X_{t}\right)$ dapat didekati dengan dua pendekatan, yaitu pendekatan regresi parametrik dan pendekatan nonparametrik. Pendekatan regresi parametrik dilakukan jika asumsi bentuk $f$ diketahui berdasarkan informasi sebelumnya dan teori, ataupun pengalaman masa lalu. Sedangkan pendekatan regresi nonparametrik dilakukan jika asumsi bentuk $f$ tidak diketahui dan kurva regresi diasumsikan mulus atau smooth.

Model regresi nonparametrik dapat berbentuk apa saja, baik linear maupun nonlinear dikarenakan tidak adanya asumsi yang harus dipenuhi. Ada beberapa teknik pendugaan nilai peubah respon dalam regresi nonparametrik, yakni Kernel, Spline, Polinomial Lokal, Deret Fourier dan Wavelet. Model regresi nonparametrik secara matematis dapat ditulis:

$$
Y_{t}=m\left(x_{t}\right)+u_{t}
$$

dengan $u_{t}$ adalah galat yang diasumsikan terdistribusi di sekitar $0, m(x)$ adalah sebuah fungsi yang mewakili perilaku intrinsik dari data. Regresi nonparametrik yang digunakan pada penelitian ini adalah regresi nonparametrik Kernel.

\subsection{Estimator Kernel}

\section{Definisi 2.1 (Hardle, 1990)}

Fungsi Kernel adalah fungsi $K: \mathbb{R} \rightarrow \mathbb{R}$ yang kontinu, terbatas dan simetris dengan nilai integral sama dengan satu,

$$
\int_{-\infty}^{\infty} K(x) d x=1
$$

Dari definisi 2.1, jika $K$ adalah fungsi nonnegatif maka $K$ juga diartikan sebagai suatu fungsi densitas.

Fungsi Kernel $K$ memiliki sifat-sifat berikut (Eubank, 1999) :

$$
\begin{array}{ll}
\text { 1. } & \int_{-\infty}^{\infty} K(u) d u=1 \\
\text { 2. } & \int_{-\infty}^{\infty} u K(u) d u=0 \\
\text { 3. } & \int_{-\infty}^{\infty} u^{2} K(u) d u=\alpha \neq 0 \\
\text { 4. } & \int_{-\infty}^{\infty} K^{2}(u) d u<\infty
\end{array}
$$

Definisi 2.2 (Hardle, 1994)

Estimator densitas Kernel multivariat untuk fungsi densitas $m(x)$ didefisikan sebagai

$m(x)=\frac{1}{n} \sum_{t=1}^{n} \prod_{j=1}^{d} \frac{1}{h_{j}} K\left(\frac{x_{t j}-X_{j}}{h_{j}}\right)$

dengan

$m(x)$ : fungsi regresi $x$ terhadap $y$

$x_{j} \quad$ : variabel prediktor ke- $j$

$K \quad$ : fungsi Kernel $d \quad$ : banyak variabel prediktor

$h_{j} \quad:$ bandwidth atau smoothing parameter untuk variabel prediktor ke- $j$

$n \quad$ : banyak data

Beberapa fungsi Kernel diantaranya adalah (Carmona, 2004) :

a. Kernel Gaussian

$$
K(u)=\frac{1}{\sqrt{2 \pi}} e^{\frac{-u^{2}}{2}},-\infty<u<\infty .
$$

b. Kernel Segitiga

$$
K(u)=\left\{\begin{array}{ll}
1-|u|, & |u| \leq 1 \\
0, & |u|>1
\end{array} .\right.
$$

c. Kernel Kuartik

$$
K(u)=\left\{\begin{array}{c}
\frac{15}{16}\left(1-u^{2}\right)^{2}, \text { untuk }|u| \leq 1 \\
0, \text { untuk }|u|>1
\end{array} .\right.
$$

d. Kernel Parzen

$$
K(u)=
$$

$$
\left\{\begin{array}{crl}
\left(\frac{9}{8}\right)-\left(\frac{3}{2}\right)|u|+\frac{u^{2}}{2}, & \text { untuk } \frac{1}{2} \leq|u| \leq \frac{3}{2} \\
\left(\frac{3}{4}\right)-u^{2}, & \text { untuk }|u| \leq \frac{1}{2} \\
0, & \text { untuk }|u| \geq \frac{3}{2}
\end{array}\right.
$$

e. Uniform

$$
K(u)=\frac{1}{2}, \text { untuk }|u| \leq 1 \text {. }
$$

f. Cosinus

$$
K(u)=\left\{\begin{array}{c}
\frac{\pi}{4} \cos \left(\frac{\pi}{2} u\right), \text { untuk }|u| \leq 1 \\
0, \quad \text { untuk u yang lain }
\end{array} .\right.
$$

g. Triweight

$$
K(u)=\left\{\begin{array}{l}
\frac{35}{32}\left(1-u^{2}\right)^{3}, \text { untuk }|u| \leq 1 \\
0, \quad \text { untuk } u \text { yang lain }
\end{array}\right.
$$

h. Epanecnhikov

$$
K(u)=\left\{\begin{array}{l}
\frac{3}{4}\left(1-x^{2}\right), \text { untuk }|u| \leq 1 \\
0, \quad \text { untuk u yang lain }
\end{array} .\right.
$$

\subsection{Estimator Nadaraya-Watson}

Untuk mengkonstruksi penduga Nadaraya-Watson diasumsikan bahwa baik variabel prediktor maupun variabel respon, keduanya adalah variabel random. Misalkan $f(x)$ adalah fungsi densitas untuk variabel random $X, f(y)$ adalah densitas untuk variabel random $Y$ dan $f(x, y)$ adalah densitas gabungan untuk variabel random $(X, Y)$, maka:

$$
m(x)=\frac{1}{f_{X}(x)} \int_{-\infty}^{\infty} y f(x, y) d y
$$


dengan mengadopsi estimator densitas Kernel, yaitu salah satu metode yang paling sederhana dari pendugaan $f(x, y)$ dan $f_{X}(x)$.

$\hat{f}(x, y)=\frac{1}{n h_{x} h_{y}} \sum_{i=1}^{n} K_{x}\left(\frac{x-X_{i}}{h_{x}}\right) K_{y}\left(\frac{y-Y_{i}}{h_{y}}\right)$

$\hat{f}_{X}(x)=\frac{1}{n h_{x}} \sum_{i=1}^{n} K_{x}\left(\frac{x-X_{i}}{h_{x}}\right)$

dimana $K_{x}($.$) dan K_{y}($.$) adalah sebuah fungsi$ Kernel, sedangkan $h_{x}$ dan $h_{y}$ adalah sebuah bilangan positif yang disebut dengan bandwidth. Selanjutnya karena

$\widehat{m}(x)=\frac{1}{\hat{f}_{X}(x)} \int_{-\infty}^{\infty} y \hat{f}(x, y) d y$

maka didapatkan estimator Nadaraya-Watson sebagai berikut:

$$
\widehat{m}(x)=\frac{\sum_{t=1}^{n} K\left(\frac{x-X_{t}}{h}\right) Y_{t}}{\sum_{t=1}^{n} K_{i}\left(\frac{x-X_{t}}{h}\right)} .
$$

Estimator dalam Persamaan (2.17) seringkali digunakan dalam dalam kasus $X_{t}$ random (Eubank, 1999).

Estimator Kernel dibagi menjadi tiga macam (Kurniasih, 2013):

1. Nadaraya-Watson

a. Univariat

$$
m(x)=\frac{\sum_{t=1}^{n} K\left(\frac{x-x_{t}}{h}\right) y_{t}}{\sum_{i=1}^{n} K\left(\frac{x-x_{t}}{h}\right)} .
$$

b. Multivariat

$$
m(x)=\frac{\sum_{t=1}^{n} \prod_{j=1}^{d} K\left(\frac{x_{t j}-x_{t}}{h_{j}}\right) y_{t}}{\sum_{t=1}^{n} \Pi_{j=1}^{d} K\left(\frac{x_{t j}-x_{t}}{h_{j}}\right)} .
$$

2. Priestley-Chao

$$
m(x)=\frac{1}{h} \sum_{t=1}^{n}\left(x-x_{t-1}\right) y_{t} K\left(\frac{x-x_{t}}{h}\right) \text {. }
$$

3. Gasser-Muller

$$
m(x)=\frac{1}{h} \sum_{t=1}^{n} y_{t} \int_{s_{t-1}}^{s_{t}} K\left(\frac{x-x_{t}}{h}\right) d x .
$$

$$
\begin{array}{ll}
\text { dengan } & \\
m(x) & \text { : fungsi regresi } x \text { terhadap } y \\
x_{j} & \text { : variabel prediktor ke- } j \\
K & \text { : fungsi Kernel } \\
n & \text { : banyak data } \\
d & \text { : banyak variabel prediktor } \\
h & \text { : bandwidth atau parameter smoothing } \\
y_{t} & \text { : variabel respon data ke- } t
\end{array}
$$

\subsection{Pemilihan Bandwidth}

Pemilihan bandwidth optimal memiliki peranan penting dalam analisis regresi. Salah satu metode yang digunakan untuk menentukan bandwidth optimal adalah dengan Generalized Cross Validation (GCV). Metode Generalized Cross Validation (GCV) dirumuskan sebagai berikut.

$$
\begin{aligned}
G C V & =\frac{M S E}{\left(n^{-1} \operatorname{tr}[I-H(h)]\right)^{2}} \\
M S E & =n^{-1} \sum_{t=1}^{n}\left(Y_{t}-\widehat{m}\left(X_{t}\right)\right)^{2}
\end{aligned}
$$

dengan Persamaan (2.22) menjadi

$G C V=\frac{n^{-1} \sum_{t=1}^{n}\left(Y_{t}-\widehat{m}\left(X_{t}\right)\right)^{2}}{\left(n^{-1} \operatorname{tr}[I-H(h)]\right)^{2}}$

\subsection{Error Berkorelasi dalam Regresi Nonparametrik}

Pada regresi parametrik maupun nonparametrik, kehadiran dari error yang berkorelasi akan merusak estimasi parameter pada model regresi. Error adalah nilai selisih dari variabel respon sebenarnya dengan nilai hasil estimasi, didefinisikan sebagai berikut:

$$
u_{t}=Y_{t}-\hat{Y}_{t}
$$

Pada regresi nonparametrik korelasi error dapat menyebabkan seleksi bandwidth menjadi rusak, karena jika korelasi error makin meningkat maka nilai bandwidth akan semakin kecil. Berdasarkan Persamaan (2.2) fungsi $m($.$) adalah fungsi yang$ tidak diketahui dan merupakan fungsi penghalus (smooth), dan vektor error $\boldsymbol{u}=\left(u_{1}, \ldots, u_{n}\right)$ memiliki varian-covarian matriks $\operatorname{Var}(e)=\sigma^{2} \boldsymbol{C}$ (Opsomer et al., 2001).

Nilai bandwidth sangat menentukan nilai estimator sehingga jika nilai bandwidth kecil maka estimator akan semakin kurang smooth dan hal tersebut tentu akan mempengaruhi model regresi. Error yang berkorelasi artinya error yang membentuk suatu pola tertentu dalam model regresi (Yang, 2001).

\subsection{Transformasi Prewhitening}

Filter prewhitening adalah sebuah invers transformasi antara variabel input dan white noise. Jika terdapat autokorelasi pada variabel input maka dibutuhkan prewhitening. Prewhitening juga digunakan untuk menghilangkan autokorelasi pada saaat korelasi silang (Yaffee and Mc Gee, 1999). 
Pada Persamaan (2.2) error $u_{i}$ adalah error yang tidak white noise, oleh karena itu error $u_{i}$ diasumsikan mengikuti $\operatorname{ARMA}(p, q)$ yaitu

$$
\begin{aligned}
\emptyset_{x}(B) X_{t} & =\theta_{x}(B) a_{t} \\
a_{t} & =\frac{\emptyset_{x}(B)}{\theta_{x}(B)} X_{t} \\
a_{t} & =\emptyset_{x}(B) \theta_{x}(B)^{-1} X_{t},
\end{aligned}
$$

dengan

$\emptyset_{x}$ : parameter autoregresi deret $X_{t}$

$\theta_{x}$ : parameter moving average deret $X_{t}$

$B$ : operator lag

Dimana $a_{t}$ adalah white noise dengan varian $\sigma_{a}{ }^{2}$ pada Persamaan (2.26) notasi $\emptyset_{x}(B) \varphi_{x}(B)^{-1}$ adalah sebuah fiter yang digunakan $X_{t}$ untuk menghasilkan white noise yang disebut prewhitening (Montgomery, 2001).

Model-model yang dapat diikuti oleh error $u_{t}$ diantaranya adalah AR $(p)$, MA $(q)$ dan ARMA $(p, q)$. Jika error $u_{t}$ adalah model AR $(p)$ maka dari Persamaan (2.26) menjadi

$a_{t}=\emptyset_{j}(B) X_{t}$

dengan memisalkan $a_{t}=\varepsilon_{t}$ dan $X_{t}=u_{t}$ maka,

$\varepsilon_{t}=\emptyset_{j}(B) u_{t}$

Jika regresi pada Persamaan (2.2) dikalikan dengan $\emptyset_{j}(B)$ (Hadijati, 2005) maka akan didapatkan

$\emptyset_{j}(B) Y_{t}=\emptyset_{j}(B) m\left(X_{t}\right)+\emptyset_{j}(B) u_{t}$

dari Persamaan (2.28) menjadi

$$
\begin{aligned}
& \emptyset_{j}(B) Y_{i}=\emptyset_{j}(B) m\left(X_{i}\right)+\varepsilon_{t}, \\
\Leftrightarrow & \left(1-\sum_{j=1}^{\infty} \emptyset_{j} B^{j}\right) Y_{t}=\left(1-\sum_{j=1}^{\infty} \emptyset_{j} B^{j}\right) m\left(X_{t}\right)+ \\
& \varepsilon_{t}, \\
\Leftrightarrow & Y_{t}-\sum_{j=1}^{\infty} \emptyset_{j} Y_{t-j}=m\left(X_{t}\right)-\sum_{j=1}^{\infty} \emptyset_{j} m\left(X_{t-j}\right)+ \\
& \varepsilon_{t}, \\
\Leftrightarrow & Y_{t}-\sum_{j=1}^{\infty} \emptyset_{j} Y_{t-j}+\sum_{j=1}^{\infty} \emptyset_{j} m\left(X_{t-j}\right)= \\
& m\left(X_{t}\right)+\varepsilon_{t}, \\
\Leftrightarrow & m\left(X_{t}\right)+\varepsilon_{t}=Y_{t}-\sum_{j=1}^{\infty} \emptyset_{j} Y_{t-j}+ \\
\sum_{j=1}^{\infty} \emptyset_{j} m\left(X_{t-j}\right), & \\
\Leftrightarrow & Y_{t}^{*}=Y_{t}-\sum_{j=1}^{\infty} \emptyset_{j} Y_{t-j}+\sum_{j=1}^{\infty} \emptyset_{j} m\left(X_{t-j}\right)
\end{aligned}
$$

sehingga Persamaan (2.30) dapat dituliskan

$Y_{t}^{*}=Y_{t}-\sum_{j=1}^{\infty} \emptyset_{j}\left(Y_{t-j}-m\left(X_{t-j}\right)\right)$,

dengan $m\left(X_{t-j}\right)$ adalah estimator Kernel konvensional yang telah didapatkan sebelumnya. Untuk memperoleh nilai $\emptyset_{j}$ dapat dilakukan sebagai berikut. Misalkan $\emptyset_{j}=a_{j}$ dan $u_{t}=z_{t}$. Bentuk autoregresi dari error $u_{t}$ adalah

$u_{t}=\emptyset_{1} u_{t-1}+\emptyset_{2} u_{t-2}+\cdots+\emptyset_{j} u_{t-j}+\cdots+\varepsilon_{t}$ atau

$z_{t}=a_{1} z_{t-1}+a_{2} z_{t-2}+\cdots+a_{j} z_{t-j}+\cdots+\varepsilon_{t}$

dari Persamaan (2.32) dapat dibentuk matriks sebagai berikut :

$\left(\begin{array}{c}z_{\tau} \\ z_{\tau+1} \\ \vdots \\ \vdots \\ z_{n}\end{array}\right)=\left(\begin{array}{cccc}z_{\tau-1} & z_{\tau-2} & \cdots & z_{\tau-\tau} \\ z_{(\tau+1)-1} & z_{(\tau+1)-2} & \cdots & z_{z+1)-\tau} \\ \vdots & \vdots & \vdots & \vdots \\ z_{n-1} & z_{n-2} & \cdots & z_{n-\tau}\end{array}\right)\left(\begin{array}{c}a_{1} \\ a_{2} \\ \vdots \\ \vdots \\ a_{\tau}\end{array}\right)+\left(\begin{array}{c}\varepsilon_{\tau} \\ \varepsilon_{\tau+1} \\ \vdots \\ \vdots \\ \varepsilon_{n}\end{array}\right)$,

$\operatorname{dengan}\left(\begin{array}{c}z_{\tau} \\ z_{\tau+1} \\ \vdots \\ z_{n}\end{array}\right)=\boldsymbol{Z},\left(\begin{array}{cccc}z_{\tau-1} & z_{\tau-2} & \ldots & z_{\tau-\tau} \\ z_{(\tau+1)-1} & z_{(\tau+1)-2} & \cdots & z_{(\tau+1)-\tau} \\ \vdots & \vdots & \vdots & \vdots \\ z_{n-1} & z_{n-2} & \cdots & z_{n-\tau}\end{array}\right)=Z_{\tau}$, $\left(\begin{array}{c}a_{1} \\ a_{2} \\ \vdots \\ a_{\tau}\end{array}\right)=\boldsymbol{a}, \operatorname{dan}\left(\begin{array}{c}\varepsilon_{\tau} \\ \varepsilon_{\tau+1} \\ \vdots \\ \varepsilon_{n}\end{array}\right)=\boldsymbol{\varepsilon}$

$z=Z_{\tau} a+\varepsilon$

dengan membentuk jumlah kuadrat error dari Persamaan (2.31) kemudian menurunkan terhadap $\boldsymbol{a}$, diperoleh

$a=\left(Z_{\tau}{ }^{\prime} Z_{\tau}\right)^{-1} Z_{\tau}{ }^{\prime} Z$

Hal serupa juga berlaku untuk error yang mengikuti model MA $(q)$ maupun $\operatorname{ARMA}(p, q)$.

\subsection{Uji Asumsi Error}

Nilai error yang didapatkan harus memenuhi asumsi identik dan independen untuk memperoleh model regresi baik.

\subsubsection{Uji Identik}

Uji identik pada error merupakan uji homogenitas varian pada error. Uji yang digunakan adalah uji Gletser dengan hipotesis sebagai berikut.

1) Hipotesis

$$
\begin{aligned}
H_{0}: & s_{1}{ }^{2}=s_{2}{ }^{2}=\cdots=s_{60}{ }^{2} \text { (error mempunyai } \\
& \text { varian yang sama) }
\end{aligned}
$$


$H_{1}:{s_{1}}^{2} \neq s_{2}{ }^{2} \neq \cdots \neq s_{60}{ }^{2}$ (error mempunyai varian berbeda)

2) Menentukan tingkat signifikansi

Dengan tingkat signifikansi $\alpha=0.05$.

3) Statistik uji

$F=\frac{\left[\sum_{t=1}^{n}\left(\left|u_{t}\right|-\left|\overline{u_{t}}\right|\right)^{2}\right](p)}{\left[\sum_{t=1}^{n}\left(\left|u_{t}\right|-\left|\overline{u_{t}}\right|\right)^{2}\right](n-p-1)}$

dengan

$n$ : banyak data

$p$ : banyak variabel prediktor

$u_{t}:$ error ke- $t$

$\bar{u}_{t}$ : rata-rata residual

4) Daerah penolakan $H_{0}$

Kriteria pengambilan keputusan, $H_{0}$ ditolak jika $F_{\text {hitung }} \geq F_{\alpha ; p ;(n-p-1)}$ atau $\quad p$-value $<\alpha$. Hal ini berarti error tidak bersifat identik.

\subsubsection{Uji Independen}

Uji independen pada error bertujuan untuk mengetahui adanya korelasi antar error atau yang biasa disebut autokorelasi. Untuk mendeteksi adanya autokorelasi dapat menggunakan uji Durbin Watson dengan hipotesis sebagai berikut.

1) Hipotesis

$H_{0}: \rho=0 \quad$ (tidak ada autokorelasi)

$H_{1}: \rho \neq 0 \quad$ (ada autokorelasi)

2) Menentukan tingkat signifikansi

Tingkat signifikansi yang digunakan adalah $\alpha=$ 0.05 .

3) Statistik uji

$d_{\text {hitung }}=\frac{\sum_{t=2}^{n}\left(\varepsilon_{t}-\varepsilon_{t-1}\right)^{2}}{\sum_{t=1}^{n} \varepsilon_{t}^{2}}$

4) Kriteria pengambilan keputusan, $H_{0}$ ditolak jika $0<d_{\text {hitung }}<d L$.

\section{Metode Penelitian}

\subsection{Sumber Data}

Data yang digunakan dalam penelitian ini adalah data Indeks Harga Saham Gabungan (IHSG) dalam indeks (1000), KURS rupiah terhadap dollar (Rupiah) dan Inflasi (\%) dan merupakan data bulanan mulai bulan Januari 2013 sampai bulan Desember 2017.

\subsection{Identifikasi Variabel}

Variabel yang digunakan pada penelitian ini terdiri dari Indeks Harga Saham Gabungan (IHSG) sebagai variabel respon $(y)$, KURS rupiah terhadap dollar sebagai variabel prediktor $1\left(x_{1}\right)$, Inflasi sebagai variabel prediktor $2\left(x_{2}\right)$.

Dalam analisis data beberapa tahapan dilakukan yaitu:

1. Membuat scatterplot masing-masing variabel yaitu scatterplot variabel $X_{1 i}$ terhdap variabel $Y_{t}$ dan scatterplot variabel $X_{2 i}$ terhdap variabel $Y_{t}$.

2. Menentukan fungsi Kernel yang digunakan. Dalam penelitian ini digunakan fungsi Kernel epacechnikov.

3. Menentukan bandwidth optimum menggunakan GCV.

4. Estimasi parameter menggunakan estimator Nadaraya-Watson.

5. Menentukan model regresi.

6. Menetukan error dari model regresi

7. Uji terhadap error menggunakan uji gletser untuk menentukan error identik atau tidak dan menggunakan uji Durbin-Watson untuk menentukan error independen atau tidak.

8. Jika error yang diperoleh berkorelasi maka dilakukan suatu metode transformasi, yaitu transformasi prewhitening terhadap error untuk memperoleh error yang tidak berkorelasi.

9. Dari proses transformasi prewhitening diperoleh $Y_{t}$ tersaring.

10. Dari nilai $Y_{t}$ tersaring tersebut, dilakukan kembali langkah ke 2-7.

11. Menentukan nilai MSE dari kedua model yang telah diperoleh.

12. Kesimpulan, dalam tahap ini akan diperlihatkan model regresi nonparametrik Kernel dengan membandingkan model terbaik antara model regresi konvensional dan model regresi hasil transformasi prewhitening.

\section{Hasil dan Pembahasan}

Sejumlah $n$ pasangan data $\left\{\left(X_{1 t} X_{2 t}, Y_{t}\right)\right\}_{t=1}^{n}$ mengikuti model regresi nonparametrik

$Y_{i}=m\left(X_{t}\right)+u_{t}, t=1,2, \ldots, n$

dengan error $u_{t}$ yang berkorelasi, memenuhi $E\left(u_{t} \mid X_{1}, X_{2}\right)=0$.

Asumsi kurva fungsi $m($.$) tidak diketahui tetapi$ smooth, sehingga dapat dilakukan dengan pendekatan estimasi Kernel. Dalam mengestimasi fungsi $m($. korelasi error tidak diabaikan, dengan proses prewhitening pada model regresi Kernel konvensional sehingga regresi yang sudah melalui proses transformasi prewhitening memiliki bentuk error yang tidak berkorelasi. Untuk memperoleh 
error yang tidak berkorelasi, error $u_{t}$ diasumsikan mengikuti model $\operatorname{ARMA}(p, q)$.

\subsection{Estimasi Model Regresi Kernel Bivariat dengan Estimator Nadaraya Watson Konvensional}

Untuk kasus $X_{t}$ acak dapat diestimasi dengan salah satu estimator Kernel yang dikenal dengan estimator Nadaraya Watson. Selanjutnya penentuan $\widehat{m}(X)$ untuk mengestimasi kurva regresi yang merupakan ekspektasi bersyarat, $m(X)=E\left(Y_{t} \mid X_{1 t}, X_{2 t}\right)$.

Densitas bersyarat untuk $Y_{t}$, jika diberikan $X_{1 t}, X_{2 t}$ adalah

$$
f_{Y_{t} \mid X_{1 t}, X_{2 t}}\left(y \mid x_{1}, x_{2}\right)=\frac{f\left(x_{1}, x_{2}, y\right)}{f\left(x_{1}, x_{2}\right)}
$$

dengan memisalkan $\left(X_{1 t}, X_{2 t}, Y_{t}\right)$ memiliki densitas bersama yaitu $f\left(x_{1}, x_{2}, y\right)$ dan densitas marginal untuk $X_{1 t}, X_{2 t}$ adalah

$f_{X_{1 t}, X_{2 t}}\left(x_{1}, x_{2}\right)=\int_{-\infty}^{\infty} f\left(x_{1}, x_{2}, y\right) d y$

sehingga

$$
\begin{aligned}
m(x) & =E\left(Y_{t} \mid X_{1 t}, X_{2 t}\right), \\
& =\int_{-\infty}^{\infty} y f_{Y_{t} \mid X_{1}, X_{2 t}}\left(y \mid x_{1}, x_{2}\right) d y, \\
& =\int_{-\infty}^{\infty} y \frac{f\left(x_{1}, x_{2}, y\right)}{f\left(x_{1}, x_{2}\right)} d y, \\
& =\frac{\int_{-\infty}^{\infty} y f\left(x_{1}, x_{2}, y\right) d y}{\int_{-\infty}^{\infty} f\left(x_{1}, x_{2}, y\right) d y}
\end{aligned}
$$

Untuk mengestimasi densitas $f\left(x_{1}, x_{2}, y\right)$ yang tidak diketahui, dapat digunakan perkalian estimator densitas Kernel dengan fungsi Kernel $K$ dan bandwidth $h$ sebagai berikut.

$\hat{f}_{h}\left(x_{1}, x_{2}, y\right)=$

$\frac{1}{n h_{1} h_{2} h_{3}} \sum_{t=1}^{n} K\left(\frac{x_{1}-X_{1 t}}{h_{1}}\right) K\left(\frac{x_{2}-X_{2 t}}{h_{2}}\right) K\left(\frac{y-Y_{t}}{h_{3}}\right)$

dan berdasarkan definisi 2.2 estimator Kernel dengan fungsi Kernel $K$ dan bandwidth $h$ didefinisikan

$\hat{f}_{h}(x)=\frac{1}{n h} \sum_{i=1}^{n}\left(\frac{x-X_{t}}{h}\right)$

Oleh karena itu, penyebut pada Persamaan (4.4) menjadi:

$$
\begin{aligned}
& \quad \int_{-\infty}^{\infty} \hat{f}_{h_{1} h_{2} h_{3}}\left(x_{1}, x_{2}, y\right) d y= \\
& \int_{-\infty}^{\infty} \frac{1}{n h_{1} h_{2} h_{3}} \sum_{t=1}^{n} K\left(\frac{x_{1}-X_{1 t}}{h_{1}}\right) K\left(\frac{x_{2}-X_{2 t}}{h_{2}}\right) K\left(\frac{y-Y_{t}}{h_{3}}\right) d y, \\
& \quad= \\
& \frac{1}{n h_{1} h_{2} h_{3}} \sum_{t=1}^{n} K\left(\frac{x_{1}-X_{1 t}}{h_{1}}\right) K\left(\frac{x_{2}-X_{2 t}}{h_{2}}\right) \int_{-\infty}^{\infty} K\left(\frac{y-Y_{t}}{h_{3}}\right) d y, \\
& \operatorname{misal} u=\frac{y-Y_{t}}{h_{3}} \rightarrow d u=\frac{1}{h_{3}} d y, \text { maka: } \\
& \int_{-\infty}^{\infty} \hat{f}_{h_{1} h_{2} h_{3}}\left(x_{1}, x_{2}, y\right) d y= \\
& \frac{1}{n h_{1} h_{2} h_{3}} \sum_{t=1}^{n} K\left(\frac{x_{1}-X_{1 t}}{h_{1}}\right) K\left(\frac{x_{2}-X_{2 t}}{h_{2}}\right) h_{3} \int_{-\infty}^{\infty} K(u) d u,
\end{aligned}
$$

Karena $\int_{-\infty}^{\infty} K(u) d u=1$, maka:

$\int_{-\infty}^{\infty} \hat{f}_{h_{1} h_{2} h_{3}}\left(x_{1}, x_{2}, y\right) d y=\frac{1}{n h_{1} h_{2}} \sum_{t=1}^{n} K\left(\frac{x_{1}-X_{1 t}}{h_{1}}\right) K\left(\frac{x_{2}-X_{2 t}}{h_{2}}\right)$

selanjutnya, pembilang dari persamaan dihasilkan sebagai berikut:

$\int_{-\infty}^{\infty} y \hat{f}_{h_{1} h_{2} h_{3}}\left(x_{1}, x_{2}, y\right) d y$

$\int_{-\infty}^{\infty} y \frac{1}{n h_{1} h_{2} h_{3}} \sum_{t=1}^{n} K\left(\frac{x_{1}-X_{1 t}}{h_{1}}\right) K\left(\frac{x_{2}-X_{2 t}}{h_{2}}\right) K\left(\frac{y-Y_{t}}{h_{3}}\right) d y$,

$=$

$\frac{1}{n h_{1} h_{2} h_{3}} \sum_{t=1}^{n} K\left(\frac{x_{1}-X_{1 t}}{h_{1}}\right) K\left(\frac{x_{2}-X_{2 t}}{h_{2}}\right) \int_{-\infty}^{\infty} K\left(\frac{y-Y_{t}}{h_{3}}\right) d y$

misal $u=\frac{y-Y_{t}}{h_{3}}$ maka $y=Y_{t}+h u \rightarrow d u=\frac{1}{h_{3}} d y$ sehingga

$\int_{-\infty}^{\infty} y \hat{f}_{h_{1} h_{2} h_{3}}\left(x_{1}, x_{2}, y\right) d y$

$\frac{1}{n h_{1} h_{2} h_{3}} \sum_{t=1}^{n} K\left(\frac{x_{1}-X_{1 t}}{h_{1}}\right) K\left(\frac{x_{2}-X_{2 t}}{h_{2}}\right) h_{3} \int_{-\infty}^{\infty}\left(Y_{t}+\right.$ $h u) K(u) d u$,

$=$

$\frac{1}{n h_{1} h_{2}} \sum_{t=1}^{n} K\left(\frac{x_{1}-X_{1 t}}{h_{1}}\right) K\left(\frac{x_{2}-X_{2 t}}{h_{2}}\right)\left[Y_{t} \int_{-\infty}^{\infty} K(u) d u+\right.$ $\left.h \int_{-\infty}^{\infty} u K(u) d u\right]$,

karena $\int_{-\infty}^{\infty} K(u) d u=1$ dan $\quad \int_{-\infty}^{\infty} u K(u) d u=0$, maka:

$\int_{-\infty}^{\infty} y \hat{f}_{h_{1} h_{2} h_{3}}\left(x_{1}, x_{2}, y\right) d y=$

$\frac{1}{n h_{1} h_{2}} \sum_{t=1}^{n} K\left(\frac{x_{1}-X_{1 t}}{h_{1}}\right) K\left(\frac{x_{2}-X_{2 t}}{h_{2}}\right) Y_{t}$ 
Berdasarkan uraian di atas, dari Persamaan (4.4) diperoleh estimator Kernel bivariat konvensional

$$
\begin{aligned}
& \widehat{m}(x)=\frac{\frac{1}{n h_{1} h_{2}} \sum_{t=1}^{n} K\left(\frac{x_{1}-X_{1 t}}{h_{1}}\right) K\left(\frac{x_{2}-X_{2} t}{h_{2}}\right) Y_{t}}{\frac{1}{n h_{1} h_{2}} \sum_{t=1}^{n} K\left(\frac{x_{1}-X_{1} t}{h_{1}}\right) K\left(\frac{x_{2}-X_{2} t}{h_{2}}\right)}, \\
& =\frac{\sum_{t=1}^{n} K\left(\frac{x_{1}-X_{1 t}}{h_{1}}\right) K\left(\frac{x_{2}-X_{2 t}}{h_{2}}\right) Y_{t}}{\sum_{t=1}^{n} K\left(\frac{x_{1}-X_{1 t}}{h_{1}}\right) K\left(\frac{x_{2}-X_{2} t}{h_{2}}\right)}
\end{aligned}
$$

\subsection{Estimasi Model Kernel Bivariat dengan Estimator Nadaraya Watson Hasil Transformasi Prewhitening}

Untuk menetapkan estimator tersaring $\widehat{m}^{*}(x)$, yaitu dari estimator $\widehat{m}(x)$ yang ditentukan dari Kernel smoothing $\hat{Y}_{t}^{*}$ berdasarkan pada Persamaan (2.28), pada dasarnya kurva regresi $m$ merupakan mean bersyarat, $m^{*}(X)=E\left(Y_{t}^{*} \mid X_{1 t}, X_{2 t}\right)$.

Densitas bersyarat untuk $Y_{t}^{*}$, jika diberikan $X_{1 t}, X_{2 t}$ adalah

$f_{Y_{t}^{*} \mid X_{1}, X_{2 t}}\left(y^{*} \mid x_{1}, x_{2}\right)=\frac{f\left(x_{1}, x_{2}, y^{*}\right)}{f\left(x_{1}, x_{2}\right)}$

dengan memisalkan $\left(X_{1 t}, X_{2 t}, Y_{t}^{*}\right)$ memiliki densitas bersama yaitu $f\left(x_{1}, x_{2}, y^{*}\right)$ dan densitas marginal untuk $X_{1 t}, X_{2 t}$ adalah

$f_{X_{1 t}, X_{2 t}}\left(x_{1}, x_{2}\right)=\int_{-\infty}^{\infty} f\left(x_{1}, x_{2}, y^{*}\right) d y$

sehingga

$$
\begin{aligned}
m(x) & =E\left(Y_{t}^{*} \mid X_{1 t}, X_{2 t}\right), \\
& =\int_{-\infty}^{\infty} y^{*} f_{Y_{t}^{*} \mid X_{1 t}, X_{2 t}}\left(y^{*} \mid x_{1}, x_{2}\right) d y, \\
& =\int_{-\infty}^{\infty} y^{*} \frac{f\left(x_{1}, x_{2}, y^{*}\right)}{f\left(x_{1}, x_{2}\right)} d y, \\
& =\frac{\int_{-\infty}^{\infty} y^{*} f\left(x_{1}, x_{2}, y^{*}\right) d y}{\int_{-\infty}^{\infty} f\left(x_{1}, x_{2}, y^{*}\right) d y}
\end{aligned}
$$

Untuk mengestimasi densitas $f\left(x_{1}, x_{2}, y^{*}\right)$ yang tidak diketahui, dapat digunakan perkalian estimator densitas Kernel dengan fungsi Kernel $K$ dan bandwidth $h$ sebagai berikut.

$\hat{f}_{h}\left(x_{1}, x_{2}, y^{*}\right)=$

$\frac{1}{n h_{4} h_{5} h_{6}} \sum_{t=1}^{n} K\left(\frac{x_{1}-X_{1 t}}{h_{4}}\right) K\left(\frac{x_{2}-X_{2 t}}{h_{5}}\right) K\left(\frac{y^{*}-Y_{t}^{*}}{h_{6}}\right)$

Oleh karena itu, penyebut pada Persamaan (4.12) menjadi:

$$
\begin{aligned}
& \int_{-\infty}^{\infty} \hat{f}_{h_{4} h_{5} h_{6}}\left(x_{1}, x_{2}, y^{*}\right) d y= \\
& \int_{-\infty}^{\infty} \frac{1}{n h_{4} h_{5} h_{6}} \sum_{t=1}^{n} K\left(\frac{x_{1}-X_{1 t}}{h_{4}}\right) K\left(\frac{x_{2}-X_{2 t}}{h_{5}}\right) K\left(\frac{y^{*}-Y_{t}^{*}}{h_{6}}\right) d y, \\
& \quad= \\
& \frac{1}{n h_{4} h_{5} h_{6}} \sum_{t=1}^{n} K\left(\frac{x_{1}-X_{1 t}}{h_{4}}\right) K\left(\frac{x_{2}-X_{2 t}}{h_{5}}\right) \int_{-\infty}^{\infty} K\left(\frac{y^{*}-Y_{t}^{*}}{h_{6}}\right) d y \\
& \operatorname{misal} u=\frac{y^{*}-Y_{t}^{*}}{h_{6}} \rightarrow d u=\frac{1}{h_{6}} d y, \text { maka: } \\
& \int_{-\infty}^{\infty} \hat{f}_{h_{4} h_{5} h_{6}}\left(x_{1}, x_{2}, y^{*}\right) d y= \\
& \frac{1}{n h_{4} h_{5} h_{6}} \sum_{t=1}^{n} K\left(\frac{x_{1}-X_{1 t}}{h_{4}}\right) K\left(\frac{x_{2}-X_{2 t}}{h_{5}}\right) h_{6} \int_{-\infty}^{\infty} K(u) d u,
\end{aligned}
$$

Karena $\int_{-\infty}^{\infty} K(u) d u=1$, maka:

$\int_{-\infty}^{\infty} \hat{f}_{h_{4} h_{5} h_{6}}\left(x_{1}, x_{2}, y^{*}\right) d y=\frac{1}{n h_{4} h_{5}} \sum_{t=1}^{n} K\left(\frac{x_{1}-X_{1 t}}{h_{4}}\right) K\left(\frac{x_{2}-X_{2 t}}{h_{5}}\right)$

selanjutnya, pembilang dari Persamaan (4.12) dihasilkan sebagai berikut:

$$
\begin{aligned}
& \int_{-\infty}^{\infty} y \hat{f}_{h_{4} h_{5} h_{6}}\left(x_{1}, x_{2}, y^{*}\right) d y= \\
& \qquad \int_{-\infty}^{\infty} y \frac{1}{n h_{4} h_{5} h_{6}} \sum_{t=1}^{n} K\left(\frac{x_{1}-X_{1 t}}{h_{4}}\right) K\left(\frac{x_{2}-X_{2 t}}{h_{5}}\right) K\left(\frac{y^{*}-Y_{t}^{*}}{h_{3}}\right) \\
& =\frac{1}{n h_{4} h_{5} h_{6}} \sum_{t=1}^{n} K\left(\frac{x_{1}-X_{1 t}}{h_{4}}\right) K\left(\frac{x_{2}-X_{2 t}}{h_{5}}\right) \int_{-\infty}^{\infty} K\left(\frac{y^{*}-Y_{t}^{*}}{h_{6}}\right) d y
\end{aligned}
$$

misal $u=\frac{y^{*}-Y_{t}}{h_{3}}$ maka $y^{*}=Y_{t}^{*}+h u \rightarrow d u=\frac{1}{h_{6}} d y$ sehingga

$\int_{-\infty}^{\infty} y \hat{f}_{h_{4} h_{5} h_{6}}\left(x_{1}, x_{2}, y^{*}\right) d y=$

$\frac{1}{n h_{4} h_{5} h_{6}} \sum_{t=1}^{n} K\left(\frac{x_{1}-X_{1 t}}{h_{4}}\right) K\left(\frac{x_{2}-X_{2 t}}{h_{5}}\right) h_{6} \int_{-\infty}^{\infty}\left(Y_{t}^{*}+\right.$ $h u) K(u) d u$,

$\frac{1}{n h_{4} h_{5}} \sum_{t=1}^{n} K\left(\frac{x_{1}-X_{1 t}}{h_{4}}\right) K\left(\frac{x_{2}-X_{2 t}}{h_{5}}\right)\left[Y_{t}^{*} \int_{-\infty}^{\infty} K(u) d u+\right.$ $\left.h_{6} \int_{-\infty}^{\infty} u K(u) d u\right]$,

karena $\int_{-\infty}^{\infty} K(u) d u=1$ dan $\int_{-\infty}^{\infty} u K(u) d u=0$, maka:

$\int_{-\infty}^{\infty} y \hat{f}_{h_{4} h_{5} h_{6}}\left(x_{1}, x_{2}, y^{*}\right) d y=$

$\frac{1}{n h_{4} h_{5}} \sum_{t=1}^{n} K\left(\frac{x_{1}-X_{1 t}}{h_{4}}\right) K\left(\frac{x_{2}-X_{2 t}}{h_{5}}\right) Y_{t}^{*}$

Berdasarkan uraian di atas, dari Persamaan (4.4) diperoleh estimator Kernel bivariat hasil transformasi prewhitening 


$$
\begin{aligned}
& \widehat{m}^{*}(x)=\frac{\frac{1}{n h_{4} h_{5}} \sum_{t=1}^{n} K\left(\frac{x_{1}-X_{1 t}}{h_{4}}\right) K\left(\frac{x_{2}-X_{2 t}}{h_{5}}\right) Y_{t}^{*}}{\frac{1}{n h_{4} h_{5}} \sum_{t=1}^{n} K\left(\frac{x_{1}-X_{1} t}{h_{4}}\right) K\left(\frac{x_{2}-X_{2 t}}{h_{5}}\right)}, \\
& =\frac{\sum_{t=1}^{n} K\left(\frac{x_{1}-X_{1 t}}{h_{4}}\right) K\left(\frac{x_{2}-X_{2 t}}{h_{5}}\right) Y_{t}^{*}}{\sum_{t=1}^{n} K\left(\frac{x_{1}-X_{1 t}}{h_{4}}\right) K\left(\frac{x_{2}-X_{2 t}}{h_{5}}\right)}
\end{aligned}
$$

\subsection{Penerapan Prosedur Estimasi pada Data}

Data yang digunakan pada penelitian ini adalah data IHSG sebagai variabel prediktor $(y)$, kurs dan inflasi, data berjumlah 60 pada tahun 2013 sampai 2017. Diperoleh plot yang ditunjukkan pada Gambar 4.1 dan Gambar 4.2 sebagai berikut:

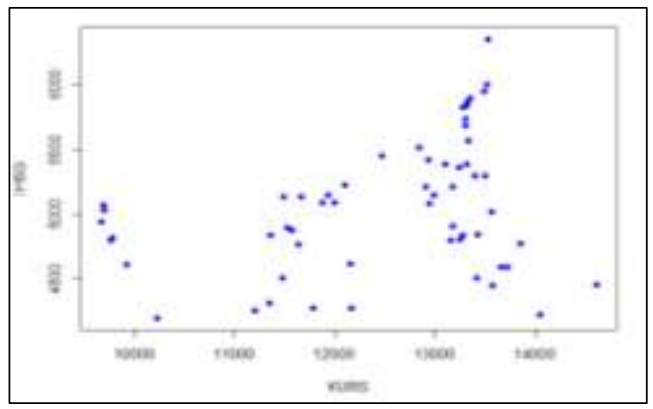

Gambar 4.1 Plot Kurs dengan IHSG

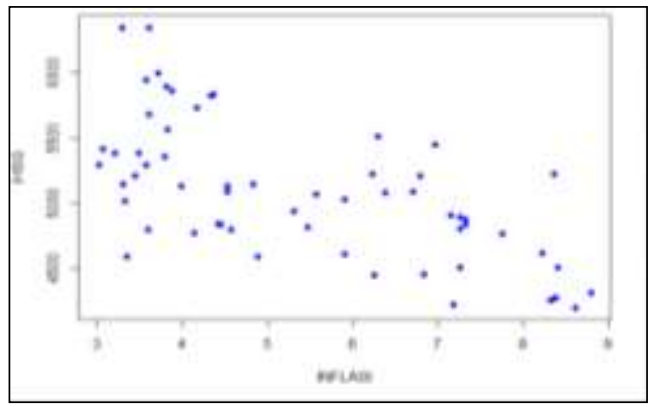

Gambar 4.2 Plot Inflasi dengan IHSG

Estimasi regresi nonparametrik yang digunakan pada penelitian ini adalah estimasi nonparametrik Kernel, salah satu estimator Kernel yang sering digunakan adalah estimator Nadaraya Watson. Estimator Nadaraya Watson bivariat seperti Persamaan (4.17) dengan menggunakan fungsi Kernel epanechnikov memiliki persamaan sebagai berikut:

$$
m(x)=\frac{\sum_{i=1}^{n}\left(\frac{3}{4}\left(1-\left(\frac{x_{1, i-x_{j}}}{h_{1}}\right)^{2}\right)\right)\left(\frac{3}{4}\left(1-\left(\frac{x_{2, i-x_{j}}}{h_{2}}\right)^{2}\right)\right) Y_{i}}{\sum_{i=1}^{n}\left(\frac{3}{4}\left(1-\left(\frac{x_{1, i-x_{j}}}{h_{1}}\right)^{2}\right)\right)\left(\frac{3}{4}\left(1-\left(\frac{x_{2, i-x_{j}}}{h_{2}}\right)^{2}\right)\right)}
$$

\subsubsection{Estimasi $\quad$ Kernel Bivariat Konvensional}

Dari data ditentukan estimator Kernel konvensional dimana dilakukan pemilihan bandwidth optimum terlebih dahulu menggunakan kriteria GCV dengan bantuan Algoritma Genetika. Dalam Algoritma Genetika digunakan populasi awal 15, mutasi genetika 0.5 dan jumlah iterasi 30 dengan batas bawah pemilian bandwidth adalah 0.056923832 dan batas atas pemilihan bandwidth adalah 3.415429892, diperoleh nilai bandwidth optimal untuk $h_{1}=0.869$ dan $h_{2}=0.319$ dengan nilai GCV $=301925$.

Tabel 4.1 Nilai Bandwidth dan GCV dari Estimator Kernel Bivariat Konvensional

\begin{tabular}{ccc}
\hline $\boldsymbol{h}_{\mathbf{1}}$ & $\boldsymbol{h}_{\mathbf{2}}$ & $\boldsymbol{G} \boldsymbol{C} \boldsymbol{V}$ \\
\hline $\mathbf{0 . 8 6 9}$ & $\mathbf{0 . 3 1 9}$ & $\mathbf{3 0 1 9 2 5}$ \\
0.869 & 0.319 & 301925 \\
0.869 & 0.319 & 301925 \\
0.869 & 0.319 & 301925 \\
0.869 & 0.319 & 301925 \\
0.869 & 0.319 & 301925 \\
0.869 & 0.319 & 301925 \\
0.869 & 0.319 & 301925 \\
0.869 & 0.319 & 301925 \\
0.869 & 0.319 & 301925 \\
0.869 & 0.319 & 301925 \\
0.869 & 0.319 & 301925 \\
0.869 & 0.319 & 301925 \\
0.869 & 0.319 & 301925 \\
0.869 & 0.319 & 301925 \\
\hline
\end{tabular}

Estimator kurva regresi yang diperoleh menggunakan nilai bandwidth optimum dan mensubstitusikan nilai $x_{1}, x_{2}$ serta $y_{1}$ pada Persamaan (4.17) seperti berikut:

$$
\begin{aligned}
m(x) & =\frac{\sum_{i=1}^{n}\left(\frac{3}{4}\left(1-\left(\frac{x_{1, i-x_{j}}}{h_{1}}\right)^{2}\right)\right)\left(\frac{3}{4}\left(1-\left(\frac{x_{2, i-x_{j}}}{h_{2}}\right)^{2}\right)\right) Y_{i}}{\sum_{i=1}^{n}\left(\frac{3}{4}\left(1-\left(\frac{x_{1, i-x_{j}}}{h_{1}}\right)^{2}\right)\right)\left(\frac{3}{4}\left(1-\left(\frac{x_{2, i-x_{j}}}{h_{2}}\right)^{2}\right)\right)} \\
& =\frac{\left(\frac{3}{4}\left(1-\left(\frac{x_{1,1}-x_{1}}{0.869}\right)^{2}\right)\right)\left(\frac{3}{4}\left(1-\left(\frac{x_{2,1}-x_{2}}{0.319}\right)^{2}\right)\right) Y_{1}+\cdots}{\left(\frac{3}{4}\left(1-\left(\frac{x_{1,1}-x_{1}}{0.869}\right)^{2}\right)\right)\left(\frac{3}{4}\left(1-\left(\frac{x_{2,1}-x_{2}}{0.319}\right)^{2}\right)\right)+\cdots}
\end{aligned}
$$




$$
\begin{aligned}
& \frac{+\left(\frac{3}{4}\left(1-\left(\frac{x_{1,1}-x_{1}}{0.869}\right)^{2}\right)\right)\left(\frac{3}{4}\left(1-\left(\frac{x_{2,1}-x_{2}}{0.319}\right)^{2}\right)\right) Y_{60}}{+\left(\frac{3}{4}\left(1-\left(\frac{x_{1,1}-x_{1}}{0.869}\right)^{2}\right)\right)\left(\frac{3}{4}\left(1-\left(\frac{x_{2,1}-x_{2}}{0.319}\right)^{2}\right)\right)} \\
& m\left(x_{1}\right) \\
& =\frac{\left(\frac{3}{4}\left(1-\left(\frac{9766-9766}{0.869}\right)^{2}\right)\right)\left(\frac{3}{4}\left(1-\left(\frac{4.57-4.57}{0.319}\right)^{2}\right)\right) 4795.789+\cdots}{\left(\frac{3}{4}\left(1-\left(\frac{9766-9766}{0.869}\right)^{2}\right)\right)\left(\frac{3}{4}\left(1-\left(\frac{4.57-4.57}{0.319}\right)^{2}\right)\right)+\cdots} \\
& \frac{+\left(\frac{3}{4}\left(1-\left(\frac{9766-9766}{0.869}\right)^{2}\right)\right)\left(\frac{3}{4}\left(1-\left(\frac{4.57-4.57}{0.319}\right)^{2}\right)\right) 6355.654}{+\left(\frac{3}{4}\left(1-\left(\frac{9766-9766}{0.869}\right)^{2}\right)\right)\left(\frac{3}{4}\left(1-\left(\frac{4.57-4.57}{0.319}\right)^{2}\right)\right)} \\
& =4806.107
\end{aligned}
$$

\begin{tabular}{|c|c|c|}
\hline Data Aktual & Data Estimasi & Error \\
\hline 5149.888 & 5024.345 & 125.543 \\
\hline 5226.947 & 5261.713 & -34.766 \\
\hline 5226.947 & 5269.871 & -42.924 \\
\hline 5450.294 & 5178.444 & 271.850 \\
\hline 5518.675 & 4798.499 & 720.176 \\
\hline 5086.425 & 4768.157 & 318.268 \\
\hline 5216.379 & 4905.334 & 311.045 \\
\hline 4910.658 & 6163.836 & -1253.178 \\
\hline 4802.529 & 4883.907 & -81.378 \\
\hline 4509.607 & 4883.479 & -373.873 \\
\hline 4223.908 & 4988.934 & -765.025 \\
\hline 4455.180 & 5032.754 & -577.573 \\
\hline 4446.458 & 4634.293 & -187.835 \\
\hline 4593.008 & 4506.524 & 86.484 \\
\hline 4593.008 & 4607.019 & -14.012 \\
\hline 4770.956 & 4564.353 & 206.603 \\
\hline 4845.371 & 4524.049 & 321.321 \\
\hline 4838.583 & 4513.141 & 325.442 \\
\hline 4796.869 & 4569.840 & 227.029 \\
\hline 5016.647 & 4602.578 & 414.069 \\
\hline 5215.994 & 4580.198 & 635.799 \\
\hline 5386.082 & 4590.934 & 795.148 \\
\hline 5364.804 & 4560.911 & 803.893 \\
\hline 5422.542 & 4592.433 & 830.109 \\
\hline 5148.910 & 4580.689 & 568.221 \\
\hline 5296.711 & 4585.775 & 710.936 \\
\hline 5296.711 & 4612.165 & 684.546 \\
\hline 5386.692 & 4583.446 & 803.246 \\
\hline 5568.106 & 4562.775 & 1005.331 \\
\hline 5685.298 & 4575.649 & 1109.648 \\
\hline 5738.155 & 4536.744 & 1201.411 \\
\hline 5829.708 & 4522.803 & 1306.905 \\
\hline 5840.939 & 4521.675 & 1319.264 \\
\hline 5864.059 & 4558.681 & 1305.378 \\
\hline 5900.854 & 4564.189 & 1336.664 \\
\hline 6005.784 & 4578.078 & 1427.706 \\
\hline 5952.138 & 4585.445 & 1366.693 \\
\hline 6355.654 & 4602.876 & 1752.778 \\
\hline 6355.654 & 4585.041 & 1770.613 \\
\hline
\end{tabular}

Tabel 4.2 Estimasi Kernel Bivariat Konvensional

\begin{tabular}{ccc}
\hline Data Aktual & Data Estimasi & Error \\
\hline 4795.789 & 4806.107 & -10.318 \\
4940.985 & 5099.438 & -158.452 \\
5034.071 & 4967.703 & 66.368 \\
5068.628 & 5201.404 & -132.776 \\
4818.895 & 5169.299 & -350.405 \\
4610.377 & 5039.121 & -428.744 \\
4195.089 & 5393.997 & -1198.908 \\
4316.176 & 5360.547 & -536.054 \\
4510.631 & 5364.152 & -853.521 \\
4256.436 & 5383.846 & -1127.410 \\
4274.177 & 5330.377 & -1056.200 \\
4274.177 & 5251.972 & -977.795 \\
4620.216 & 5263.453 & -643.238 \\
4768.277 & 5373.060 & -604.783 \\
4840.146 & 5407.211 & -567.065 \\
4893.908 & 5398.766 & -504.858 \\
4878.582 & 5393.255 & -514.673 \\
5088.802 & 5338.441 & -249.639 \\
5136.863 & 4753.392 & 383.471 \\
5137.579 & 4606.228 & 531.351 \\
5089.547 & 4568.374 & 521.173 \\
& &
\end{tabular}

Selanjutnya pengujian error dari estimasi Kernel bivariat konvensional sebagai berikut: 
a. Uji Identik

Pengujian asumsi keidentikan dilakukan dengan menggunakan uji Gletser (Persamaan pada bab 2).

1) Hipotesis

$H_{0} \quad: \quad s_{1}{ }^{2}=s_{2}{ }^{2}=\cdots=s_{60}{ }^{2} \quad$ (error mempunyai varian yang sama)

$H_{1}: s_{1}{ }^{2} \neq s_{2}{ }^{2} \neq \cdots \neq s_{60}{ }^{2}$ (error mempunyai varian berbeda)

2) Tingkat signifikansi $a=0.05$ dan nilai $F_{\text {tabel }}=3.16$

3) Statistik uji $F=0.035$ dan nilai $p-$ value $=0.06$ (Lihat Lampiran 4 bagian a)

4) Keputusan

Karena nilai $F<F_{\text {tabel }}$ yaitu $0.035<3.16$ dan nilai $a=0.05<p-$ value $=0.065$ maka $H_{0}$ gagal tolak artinya error mempunyai varian yang sama, error bersifat identik.

\section{b. Uji Independen}

Uji Durbin Watson dilakukan untuk mengetahui apakah error independen atau tidak.

1) Hipotesis

$H_{0}: \rho=0$ (tidak ada autokorelasi)

$H_{1}: \rho \neq 0$ (ada autokorelasi)

2) Tingkat signifikansi $a=0.05$

3) Nilai statistik uji $d_{\text {hitung }}=0.214$ (Lihat Lampiran 4 bagian a)

4) Nilai $d L=1.51442$ dan nilai $d U=$ 1.65184 (diperoleh dari tabel Durbin Watson pada Lampiran 5).

5) Keputusan

Karena nilai $d_{\text {hitung }}=0.214<d L=$ 1.51442 maka $H_{0}$ ditolak artinya terdapat autokorelasi pada error, error tidak independen.

Sehingga dapat disimpulkan bahwa error yang diperoleh dari estimator Kernel konvensional tidak white-noise.

\subsubsection{Mengatasi Error Berkorelasi dengan Metode Transformasi Prewhitening}

Pada Persamaan 4.1 error $u_{t}$ diasumsikan stasioner dan mengikuti proses ARMA (p,q). Berikut plot ACF dan PACF error dari estimasi konvensional.
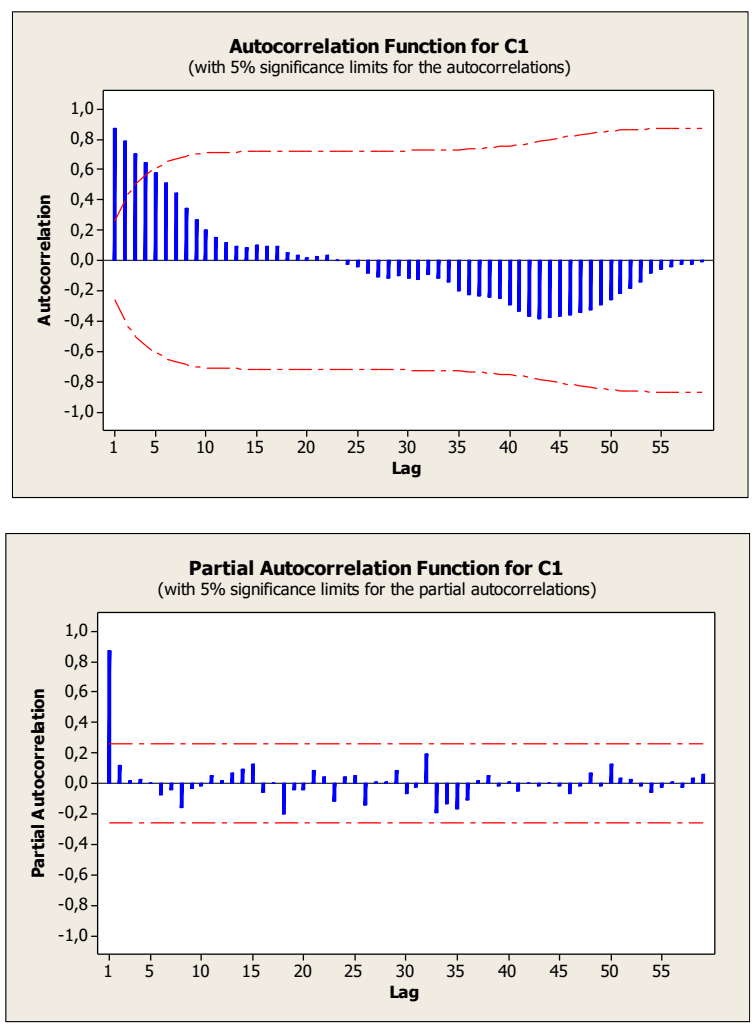

Gambar 4.3 Plot ACF dan PACF Error dari Estimator Konvensional

Dari Gambar 4.4 diperoleh model terbaik dari error adalah model AR(1) dengan model

$u_{t}=\emptyset_{1} u_{t-1}+\varepsilon_{t}$

dengan $\emptyset_{1}$ adalah parameter autoregresi orde-1. Dari Persamaan (2.32) diperoleh nilai $a_{1}$ untuk $\tau=1$ sebagai berikut:

$$
\begin{aligned}
& \left.\left(a_{1}\right)=\left(\begin{array}{llll}
z_{\tau-1} & z_{(\tau+1)-1} & \cdots & z_{n-1}
\end{array}\right]\left[\begin{array}{c}
z_{\tau-1} \\
z_{(\tau+1)-1} \\
\vdots \\
z_{n-1}
\end{array}\right]\right)^{-1} \\
& *\left(\left[\begin{array}{llll}
z_{\tau-1} & z_{(\tau+1)-1} & \cdots & z_{n-1}
\end{array}\right]\left[\begin{array}{c}
z_{1} \\
z_{2} \\
\vdots \\
z_{n}
\end{array}\right]\right) \\
& \left(a_{1}\right)= \\
& \left.\left(\begin{array}{llll}
z_{0} & z_{1} & \cdots & z_{59}
\end{array}\right]\left[\begin{array}{c}
z_{0} \\
z_{1} \\
\vdots \\
z_{59}
\end{array}\right]\right)^{-1}\left(\left[\begin{array}{llll}
z_{0} & z_{1} & \cdots & z_{59}
\end{array}\right]\left[\begin{array}{c}
z_{1} \\
z_{2} \\
\vdots \\
z_{60}
\end{array}\right]\right) \\
& \left(\left[\begin{array}{llll}
0 & 10.318355 & \cdots & 1752.778088
\end{array}\right]\left[\begin{array}{c}
0 \\
10.318355 \\
\vdots \\
1752.778088
\end{array}\right]\right)^{-1} \\
& \left.\left(\begin{array}{llll}
0 & 10.318355 & \cdots & 1752.778088
\end{array}\right]\left[\begin{array}{c}
10.318355 \\
158.452362 \\
\vdots \\
1770.612906
\end{array}\right]\right)
\end{aligned}
$$




$$
\begin{aligned}
& =\left(0^{2}+10.318355^{2}+\cdots+\right. \\
& \left.1752.778088^{2}\right)^{-1}((0 * 10.318355)+ \\
& (10.318355 * 158.452362)+\cdots+ \\
& (1752.778088 * 1770.612906)) \\
& =\frac{35217128.94}{37769962.43} \\
& =0.932
\end{aligned}
$$

Sehingga nilai dari $\emptyset_{1}=0.93$.

Model regresi yang mempunyai error yang tidak berkorelasi memiliki persamaan sebagai berikut

$Y_{t}^{*}=m\left(X_{t}\right)+\varepsilon_{t}$

Persamaan (4.19) disebut dengan model regresi tersaring, dimana $Y_{t}{ }^{*}$ adalah rangkaian data $Y_{t}$ yang tersaring. Persamaan $Y_{t}^{*}$ sebagai berikut

$Y_{t}^{*}=Y_{t}-\sum_{i=1}^{n} \emptyset_{i}\left(Y_{t-i}-\widehat{m}\left(X_{t-i}\right)\right)$

Karena error model AR(1), maka

$$
\begin{aligned}
Y_{t}^{*} & =Y_{t}-\emptyset_{1}\left(Y_{t-1}-\widehat{m}\left(X_{t-1}\right)\right) \\
& =Y_{t}-0.932\left(Y_{t-1}-\widehat{m}\left(X_{t-1}\right)\right)
\end{aligned}
$$

Dimana $\widehat{m}\left(X_{t-i}\right)$ adalah estimator Kernel konvensional yang telah didapatkan sebelumnya. Nilai $Y_{t}^{*}$ dapat dilihat pada Tabel 4.4.

\subsubsection{Estimasi Kernel Bivariat Hasil Transformasi Prewhitening}

Dari nilai $Y_{i}^{*}$ ditentukan estimator Kernel hasil transformasi prewhitening dimana dilakukan pemilihan bandwidth optimum terlebih dahulu menggunakan kriteria GCV seperti pada Tabel 4.3, diperoleh nilai bandwidth optimum untuk $h_{4}=0.33$ dan $h_{5}=0.221$ dengan nilai $G C V=531569200$.

Tabel 4.3 Nilai Bandwidth dan GCV dari Estimator Hasil Prewhitening

\begin{tabular}{ccc}
\hline $\boldsymbol{h}_{\mathbf{4}}$ & $\boldsymbol{h}_{\mathbf{5}}$ & $\boldsymbol{G C V}$ \\
\hline $\mathbf{0 . 3 3 2}$ & $\mathbf{0 . 2 2 1}$ & $\mathbf{5 3 1 5 6 9 2 0 0}$ \\
0.038 & 0.798 & 531569200 \\
0.218 & 0.662 & 531569200 \\
0.199 & 0.874 & 531569200
\end{tabular}

\begin{tabular}{ccc}
\hline $\boldsymbol{h}_{\mathbf{4}}$ & $\boldsymbol{h}_{\mathbf{5}}$ & $\boldsymbol{G C V}$ \\
\hline 0.218 & 0.662 & 531569200 \\
0.218 & 0.199 & 531569200 \\
0.199 & 0.662 & 531569200 \\
0.662 & 0.218 & 531569200 \\
0.037 & 0.798 & 531569200 \\
0.218 & 0.662 & 531569200 \\
0.662 & 0.218 & 531569200 \\
0.869 & 0.319 & 531569200 \\
0.869 & 0.319 & 531569200 \\
0.869 & 0.319 & 531569200 \\
0.869 & 0.319 & 531569200 \\
\hline
\end{tabular}

Estimator kurva regresi yang diperoleh menggunakan nilai bandwidth optimum dan mensubstitusikan nilai $X_{1}, X_{2}$ serta $Y_{1}{ }^{*}$ pada Persamaan (4.16) seperti berikut:

$$
\begin{gathered}
m(x)^{*}=\frac{\sum_{i=1}^{n}\left(\frac{3}{4}\left(1-\left(\frac{x_{1, i-x_{j}}}{h_{4}}\right)^{2}\right)\right)\left(\frac{3}{4}\left(1-\left(\frac{x_{2, i-x_{j}}}{h_{5}}\right)^{2}\right)\right) Y_{i}{ }^{*}}{\sum_{i=1}^{n}\left(\frac{3}{4}\left(1-\left(\frac{x_{1, i-x_{j}}}{h_{4}}\right)^{2}\right)\right)\left(\frac{3}{4}\left(1-\left(\frac{x_{2, i-x_{j}}}{h_{5}}\right)^{2}\right)\right)} \\
=\frac{\left(\frac{3}{4}\left(1-\left(\frac{x_{1,1}-x_{1}}{0.332}\right)^{2}\right)\right)\left(\frac{3}{4}\left(1-\left(\frac{x_{2,1}-x_{2}}{0.221}\right)^{2}\right)\right) Y_{1}{ }^{*}+\cdots}{\left(\frac{3}{4}\left(1-\left(\frac{x_{1,1}-x_{1}}{0.332}\right)^{2}\right)\right)\left(\frac{3}{4}\left(1-\left(\frac{x_{2,1}-x_{2}}{0.221}\right)^{2}\right)\right)+\cdots} \\
\frac{+\left(\frac{3}{4}\left(1-\left(\frac{x_{1,1}-x_{1}}{0.332}\right)^{2}\right)\right)\left(\frac{3}{4}\left(1-\left(\frac{x_{2,1}-x_{2}}{0.221}\right)^{2}\right)\right) Y_{60}{ }^{*}}{+\left(\frac{3}{4}\left(1-\left(\frac{x_{1,1}-x_{1}}{0.332}\right)^{2}\right)\right)\left(\frac{3}{4}\left(1-\left(\frac{x_{2,1}-x_{2}}{0.221}\right)^{2}\right)\right)}
\end{gathered}
$$

$m\left(x_{1}\right)^{*}=$

$\frac{\left(\frac{3}{4}\left(1-\left(\frac{9766-9766}{0.869}\right)^{2}\right)\right)\left(\frac{3}{4}\left(1-\left(\frac{4.57-4.57}{0.221}\right)^{2}\right)\right) 4795.789+\cdots}{\left(\frac{3}{4}\left(1-\left(\frac{9766-9766}{0.332}\right)^{2}\right)\right)\left(\frac{3}{4}\left(1-\left(\frac{4.57-4.57}{0.221}\right)^{2}\right)\right)+\cdots}$

$\frac{+\left(\frac{3}{4}\left(1-\left(\frac{9766-9766}{0.332}\right)^{2}\right)\right)\left(\frac{3}{4}\left(1-\left(\frac{4.57-4.57}{0.221}\right)^{2}\right)\right) 4722.065}{+\left(\frac{3}{4}\left(1-\left(\frac{9766-9766}{0.332}\right)^{2}\right)\right)\left(\frac{3}{4}\left(1-\left(\frac{4.57-4.57}{0.221}\right)^{2}\right)\right)}$

Diperoleh nilai estimator Kernel bivariat konvensional $Y_{1}{ }^{*}$ yaitu $m\left(x_{1}\right)^{*}=5064.639$. Dengan cara yang sama dapat dihitung nilai $Y_{2}{ }^{*}, \cdots, Y_{60}{ }^{*}$ yaitu $m\left(x_{2}\right)^{*}, \cdots, m\left(x_{60}\right)^{*}$. Berikut daftar nilai estimasi Kernel bivariat hasil transformasi prewhitening dengan bandwidth optimum disajikan pada Tabel 4.4.

Berikut daftar nilai estimasi Kenel hasil prewhitening. 
Tabel 4.4 Estimasi Kernel Bivariat Hasil Transformasi Prewhitening

\begin{tabular}{ccc}
\hline$\widehat{\boldsymbol{Y}}_{\boldsymbol{i}}^{*}$ & $\begin{array}{c}\text { Estimator } \\
\text { Prewhitening }\left(\boldsymbol{m}(\boldsymbol{x})^{*}\right)\end{array}$ & Error \\
\hline 4795.789 & 5064.639 & -268.849 \\
4950.603 & 4909.268 & 41.335 \\
5181.748 & 4793.798 & 387.950 \\
5006.773 & 4851.495 & 155.278 \\
4942.643 & 4868.754 & 73.889 \\
4936.954 & 4787.898 & 149.056 \\
4594.678 & 4722.619 & -127.941 \\
5433.558 & 4734.279 & 699.279 \\
5483.985 & 4734.279 & 749.706 \\
5051.918 & 4726.091 & 325.827 \\
5324.923 & 4749.382 & 575.541 \\
5258.556 & 4785.345 & 473.211 \\
5531.520 & 4780.287 & 751.234 \\
5418.059 & 4732.219 & 635.555 \\
5367.774 & 4718.691 & 685.111 \\
5403.804 & 4721.868 & 700.545 \\
5422.413 & 4724.044 & 625.065 \\
5349.109 & 4736.348 & 832.129 \\
5568.477 & 4911.896 & 457.631 \\
5369.527 & 4936.101 & -155.917 \\
4780.184 & 4891.504 & -297.176 \\
4594.328 & 4858.500 & -194.345 \\
4664.155 & 4745.448 & 364.492 \\
5109.940 & 4777.084 & 359.427 \\
5259.349 & 4798.079 & 692.220 \\
5490.299 & 4905.883 & 359.427 \\
5265.310 & 4923.360 & -508.139 \\
4415.221 & 4890.986 & 28.766 \\
4919.753 & 4920.671 & -299.907 \\
4620.764 & 4923.631 & 1046.859 \\
5970.491 & 4924.491 & -310.947 \\
4585.451 & 4883.305 & -271.197 \\
4572.358 & 4866.615 & 301.569 \\
5168.184 & 5007.526 & -22.769 \\
4984.757 & 5136.027 & -367.957 \\
4768.070 & 5129.931 & -617.526 \\
4512.405 & 5146.550 & -362.525 \\
4784.015 & 5124.088 & \\
4652.817 & 5092.762 & \\
& & -686 \\
& & \\
\hline & & \\
\hline
\end{tabular}

\begin{tabular}{ccc}
\hline$\widehat{\boldsymbol{Y}}_{\boldsymbol{i}}{ }^{*}$ & $\begin{array}{c}\text { Estimator } \\
\text { Prewhitening }\left(\boldsymbol{m}(\boldsymbol{x})^{*}\right)\end{array}$ & Error \\
\hline 4539.112 & 5082.577 & -289.057 \\
4493.557 & 5082.577 & -289.057 \\
4805.056 & 5101.951 & -478.224 \\
4805.082 & 5061.993 & -388.679 \\
4793.520 & 5071.182 & -695.934 \\
4623.726 & 5120.165 & -353.037 \\
4673.314 & 5105.046 & -356.351 \\
4375.249 & 5111.106 & -291.625 \\
4767.129 & 5110.494 & -474.989 \\
4634.119 & 5105.634 & -357.304 \\
4748.695 & 5123.520 & -363.507 \\
4819.481 & 5112.075 & -408.112 \\
4748.329 & 5110.599 & -400.606 \\
4709.994 & 5148.495 & -532.422 \\
4622.904 & 5114.322 & -491.418 \\
4634.505 & 5110.494 & -475.989 \\
4684.242 & 5112.312 & -428.070 \\
4760.013 & 5123.520 & -363.507 \\
4621.516 & 5119.612 & -498.096 \\
5081.896 & 5118.487 & -36.591 \\
4722.065 & 5122.340 & -400.275 \\
\hline
\end{tabular}

Selanjutnya pengujian error dari estimasi hasil transformasi prewhitening sebagai berikut.

a. Uji Identik

Pengujian asumsi keidentikan dilakukan dengan menggunakan uji Gletser (Persamaan pada bab 2).

1) Hipotesis

2) $H_{0}: s_{1}{ }^{2}=s_{2}{ }^{2}=\cdots=s_{60}{ }^{2} \quad$ (error mempunyai varian yang sama)

3) $H_{1}: s_{1}{ }^{2} \neq s_{2}{ }^{2} \neq \cdots \neq s_{60}{ }^{2}$ (error mempunyai varian berbeda)

4) Tingkat signifikansi $a=0.05$ dan $F_{\text {tabel }}=$ 3.16

5) Statistik uji $F=0.035$ dan nilai $p-$ value $=0.126($ Lihat Lampiran 4 bagian a)

6) Keputusan

Karena nilai $F<F_{\text {tabel }}$ yaitu $0.035<3.16$ dan nilai $a=0.05<p-$ value $=0.126$ maka $H_{0}$ gagal tolak artinya error mempunyai varian yang sama, error bersifat identik. 
b. Uji Independen

Uji Durbin Watson dilakukan untuk mengetahui apakah error independen atau tidak.

1) Hipotesis

$H_{0}: \rho=0$ (tidak ada autokorelasi)

$H_{1}: \rho \neq 0$ (ada autokorelasi)

2) Tingkat signifikansi $a=0.05$

3) Statistik uji $d_{\text {hitung }}=2.014 \quad$ (Lihat Lampiran 4 bagian a)

4) Nilai $d L=1.51442$ dan nilai $d U=$ 1.65184 (diperoleh dari tabel Durbin Watson pada Lampiran 5).

5) Keputusan

Karena nilai $\quad d_{\text {hitung }}=2.014>d L=$ 1.65184 maka gagal tolak $H_{0}$ artinya tidak terdapat autokorelasi pada error, error independen.

Sehingga dapat disimpulkan bahwa error yang diperoleh dari estimator Kernel hasil Prewhitening bersifat white noise karena asumsi identik dan independen terpenuhi.

\subsubsection{Efisiensi dari Estimastor Kernel Bivariat Konvensional dan Estimator Kernel Bivariat Hasil Transformasi Prewhitening}

Berikut ketepatan model estimasi jika dilihat dari kurva regresi.

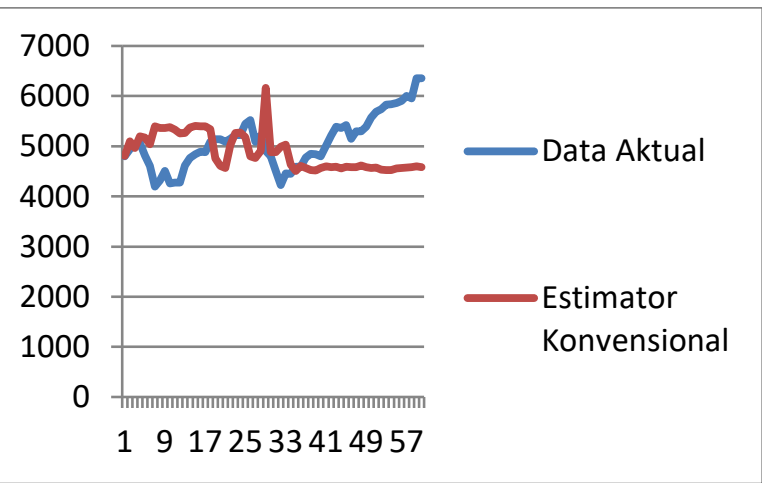

Gambar 4.4 Kurva Data Aktual dengan Data estimasi Kernel Bivariat Konvensional

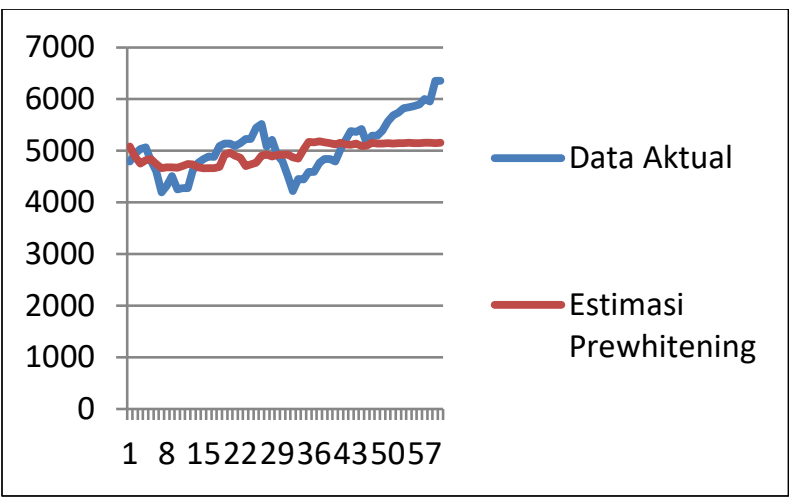

Gambar 4.5 Kurva Data Aktual dengan Data Estimasi Kernel Bivariat Hasil Prewhitening

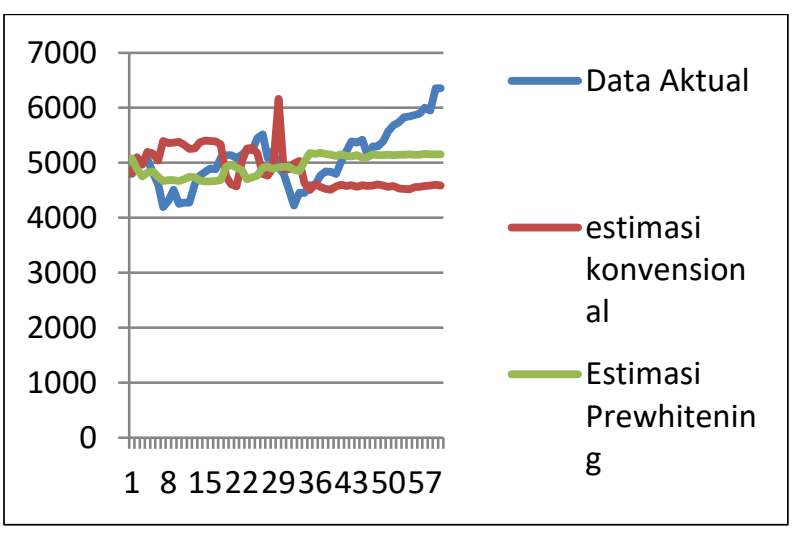

Gambar 4.6 Kurva Data Atual, Data Estimator Konvensional dan Data Estimator Hasil Prewhitening

Pada Gambar 4.4 terlihat adanya perbedaan antara estimator Kernel konvensional dengan data sebenarnya. Begitu juga pada Gambar 4.5 terlihat perbedaan antara estimator Kernel hasil transformasi prewhitening dengan data sebenarnya. Namun dari gambar tersebut belum dapat ditentukan estimator mana yang lebih baik. Oleh karena itu untuk mengetahui efisiensi dari kedua estimator dapat dilakukan dengan membandingkan nilai MSE atau nilain MAPE dari kedua estimator.

Nilai MSE dari estimator konvensional $M S E=\frac{\sum_{i=1}^{n}\left(Y_{i}-m(X)\right)^{2}}{n}$
$=\frac{\left((4795-4806.1)^{2}+(4940.9-5099.4)^{2}+\cdots+(6355.7-4585)^{2}\right)}{60}$

1) Nilai MSE dari estimator hasil transformasi prewhitening

$$
\begin{aligned}
& M S E=\frac{\sum_{i=1}^{n}\left(Y_{i}{ }^{*}-m(X)^{*}\right)^{2}}{n} \\
&= \\
& \frac{\left((5388.6-4668)^{2}+(5608.7-4685.9)^{2}+\cdots+(4585-5157)^{2}\right)}{60} \\
& \quad=290303.8317^{60}
\end{aligned}
$$


Estimator dengan nilai MSE yang lebih kecil adalah estimator yang lebih efisien atau lebih baik. Diperoleh nilai MSE dari estimator konvensional dan estimator hasil taransformasi prewhitening masingmasing adalah 639203.3084 dan 290303.8317. Sehingga dapat dikatakan bahwa estimator hasil transformasi prewhitening lebih efisien dari estimator konvensional. Selain MSE, efisiensi kedua estimator juga dapat dilihat dari nilai MAPE berdasarkan Persamaan (2.23) sebagai berikut:

$$
\begin{aligned}
& \text { 1) } M A P E=n^{-1} \sum_{i=1}^{n}\left|\frac{Y_{i}-m\left(X_{i}\right)}{Y_{i}}\right| * 100 \% \\
&= \frac{1}{60} *\left(\left|\frac{4795-4806.1}{4795}\right|+\left|\frac{4940.9-5099.4}{4940.9}\right|+\cdots+\right. \\
&\left.\left|\frac{6355.7-4585}{6355.7}\right|\right) * 100 \% \\
& \quad=12,7 \%
\end{aligned}
$$

2) $M A P E=n^{-1} \sum_{i=1}^{n}\left|\frac{Y_{i}^{*}-m\left(X_{i}\right)^{*}}{Y_{i}{ }^{*}}\right| * 100 \%$

$$
\begin{aligned}
= & \frac{1}{60} *\left(\left|\frac{5388.6-4668}{5388.6}\right|+\left|\frac{5608.7-4685.9}{5608.7}\right|+\cdots+\right. \\
= & \left.\left|\frac{4585-5157}{4585}\right|\right) * 100 \%
\end{aligned}
$$

Nilai MAPE dari estimator konvensional yaitu $12.7 \%$ lebih kecil dari nilai MAPE dari estimator hasil transformasi prewhitening yaitu $8.34 \%$ artinya estimator hasil transformasi prewhitening lebih efisien dari estimator konvensional.

\section{Penutup}

\subsection{Kesimpulan}

Dari hasil analisis dan pembahasan yang telah dilakukan, diperoleh simpulan bahwa:

a. Model estimasi Kernel bivariat konvensional dengan error berkorelasi adalah

$$
\begin{aligned}
& m(x)= \\
& \frac{\left(\frac{3}{4}\left(1-\left(\frac{x_{1,1}-x_{1}}{0.8692588}\right)^{2}\right)\right)\left(\frac{3}{4}\left(1-\left(\frac{x_{2,1}-x_{2}}{0.3192463}\right)^{2}\right)\right) Y_{1}+\cdots}{\left(\frac{3}{4}\left(1-\left(\frac{x_{1,1}-x_{1}}{0.8692588}\right)^{2}\right)\right)\left(\frac{3}{4}\left(1-\left(\frac{x_{2,1}-x_{2}}{0.3192463}\right)^{2}\right)\right)+\cdots} \\
& \quad \frac{+\left(\frac{3}{4}\left(1-\left(\frac{x_{1,1}-x_{1}}{0.8692588}\right)^{2}\right)\right)\left(\frac{3}{4}\left(1-\left(\frac{x_{2,1}-x_{2}}{0.3192463}\right)^{2}\right)\right) Y_{60}}{+\left(\frac{3}{4}\left(1-\left(\frac{x_{1,1}-x_{1}}{0.8692588}\right)^{2}\right)\right)\left(\frac{3}{4}\left(1-\left(\frac{x_{2,1}-x_{2}}{0.3192463}\right)^{2}\right)\right)}
\end{aligned}
$$

b. Model estimasi Kernel bivariat hasil transformasi prewhitening dengan error tidak berkorelasi adalah

$m(x)^{*}=\frac{\left(\frac{3}{4}\left(1-\left(\frac{x_{1,1}-x_{1}}{0.3317731}\right)^{2}\right)\right)\left(\frac{3}{4}\left(1-\left(\frac{x_{2,1}-x_{2}}{0.2213052}\right)^{2}\right)\right) Y_{1}{ }^{*}+\cdots}{\left(\frac{3}{4}\left(1-\left(\frac{x_{1,1}-x_{1}}{0.3317731}\right)^{2}\right)\right)\left(\frac{3}{4}\left(1-\left(\frac{x_{2,1}-x_{2}}{0.2213052}\right)^{2}\right)\right)+\cdots}$

$$
\frac{+\left(\frac{3}{4}\left(1-\left(\frac{x_{1,1}-x_{1}}{0.3317731}\right)^{2}\right)\right)\left(\frac{3}{4}\left(1-\left(\frac{x_{2,1}-x_{2}}{0.2213052}\right)^{2}\right)\right) Y_{60}{ }^{*}}{+\left(\frac{3}{4}\left(1-\left(\frac{x_{1,1}-x_{1}}{0.3317731}\right)^{2}\right)\right)\left(\frac{3}{4}\left(1-\left(\frac{x_{2,1}-x_{2}}{0.2213052}\right)^{2}\right)\right)}
$$

c. Nilai MSE dari estimator konvensional dan estimator hasil prewhitening masing-masing adalah 639203.3084 dan 290303.8317. Sehingga dapat dikatakan bahwa estimator hasil transformasi prewhitening lebih baik dari estimator konvensional.

\subsection{Saran}

Saran dari penelitian ini adalah

a. Melakukan proses prewhitening pada data yang didasarkan pada selain AR(1).

b. Penelitian selanjutnya diharapkan dapat menambahkan variabel prediktor yaitu faktorfaktor lain yang mempengaruhi naik turunnya IHSG.

\section{DAFTAR PUSTAKA}

Box, G.E.P., Jenkins, G.M., and Reinsel, G.C. 1994. Time Series Analysis : Forecasting and Control. $3^{\text {rd }} e d$. Prentice Hall. Inc., New York.

Budiantara, I. N., dkk. 2006. Pemodelan B-Spline dan MARS pada Nilai Ujian Masuk terhadap IPK Mahasiswa Jurusan Disain Komonikasi Visual UK. Petra Surabaya. Jurnal Teknik Industri, Vol. 8, No. 1, Hal. 1.

Carmona, A.R. 2004. Statistical of Financial Data in S-Plus. United State of America : Springer.

Data Inflasi-Bank Sentral Republik Indonesia. Diakses pada tanggal 1 November 2018 pukul 23:07.

Eubank, R.L. 1999. Spline Smoothing and Nonparametric Regression $2^{\text {nd }}$ Edition. Marcel Dekker Inc : New York.

Hadijati, M. 2005. Estimasi Kernel dalam Regresi Nonparametrik dengan Error Berkorelasi. Tesis. Surabaya : FMIPA Insitut Teknologi Sepuluh November.

Hardle, W. 1990. Smoothing Techniques With Implementation in $S$. Springer-Verlag : New York.

1994. Applied Nonparametric Regression. Berlin : Humboldt University..

IHSG,http://finance.yahoo.com/quote/\%5EJKSE/hist ory/. 10 November 2018 pukul 00:33 WITA.

Kurniasih, D. 2013. Efisiensi Relatif Estimator Fungsi Kernel Gassian Terhadap Estimator 
Polinomial Dalam Peramalan USD Terhadap $J P Y$. Skripsi. Semarang : FMIPA Universitas Negeri Semarang.

Kurs Referensi (JISDOR) - Bank Sentral Republik Indonesia. 1 November 2018 pukul 23:12 WITA.

Montgomery, D.C. Design and Analysis of Experiments. John Wiley and Sons, Inc., Arizona.

Nonparametric Regression With Correlated Errors. Statistical Science, Vol. 16, No.2.

Tabel Durbin-Watson. http://www.standford.edu. Diakses pada tanggal 28 September 2019 pukul 15:25 WITA.

Wei, W.S. 1990. Time Series Analysis Univariate and Multivariate Methods. Addison-Wesley Publishing Company, Inc., Canada.

Xiao, Z., Linton, O.B., Carrol, R.J., and Mammen, E. 2002. More Efficient Kernel Estimation in Regression with Autocorrelated Errors. Cowles Foundation.

Yaffee, R.A., and McGee, M. Introduction to Time Series Analysis and Forecasting. Academic Press, Inc., New York.

Yang, Y. 2001. Nonparametric Regression With Dependent Errors. Bernoulli, Vol. 7, No. 4. 